Jonas Meckling* and Llewelyn Hughes

\title{
Global interdependence in clean energy transitions
}

\begin{abstract}
The global energy industry is transforming as governments invest in clean energy technologies to address climate change, enhance energy security, and strengthen national competitiveness. Comparative research on clean energy transitions highlights the domestic drivers and constraints of clean energy transitions. This article contends that we need to understand the effects of global interdependence on clean energy transitions. Shifts in forms of interdependence between firms-influenced by the rise of global supply chains-have new implications for policy choices made by governments. Governments face more complex demands from domestic industries facing global economic competition, and act strategically in response to the actions of other governments, including sub-national actors, and firms in the global economy. We suggest that research on interdependence in clean energy transitions benefits from an analytical focus on mechanisms of transnational change such as cross-national and multi-level policy feedback and crossnational policy sequencing. Global interdependence has important implications for economic and environmental outcomes, affecting the durability of competitive advantage, and influencing the pace of the diffusion of clean energy technologies.
\end{abstract}

Keywords: interdependence, energy transition, industrial policy, business-government relations

doi:10.1017/bap.2018.25

\section{Introduction}

The rise of clean energy technologies is transforming the global energy industry. Global investment in clean energy technologies was US\$571 billion in 2017,

The authors contributed equally to the manuscript. We thank Henry Farrell, Kathy Hochstetler, Abe Newman, Valerie Karplus, Tobias Schmidt, Sam Trachtman, the anonymous reviewers, and the editors for helpful comments. We are grateful for research assistance by Nicholas Goedeking.

*Corresponding author: Jonas Meckling, Assistant Professor of Energy and Environmental Policy, Dept. of Environmental Science, Policy, and Management, University of California, Berkeley, 130 Mulford Hall, \#3114, Berkeley, CA 94720; Email: meckling@berkeley.edu

Llewelyn Hughes, Associate Professor of Public Policy, Crawford School of Public Policy, Australian National University, Lennox Crossing, Canberra 2601, Australia; Email: llewelyn.hughes@anu.edu.au 
reaching over 60 percent of the US\$927 billion invested globally in fossil fuels. ${ }^{1}$ Government intervention is one factor driving these investments in clean energy technologies globally. ${ }^{2}$ Green industrial policies include subsidies for producers and consumers, local content rules, and trade barriers, amongst others. Many of these tools were employed in the 1980s, when governments competed for market share in information technology, autos, aircraft, telecommunications, and electronics. ${ }^{3}$ Today, governments have shifted their attention to the energy sector in an attempt to promote growth by developing and commercializing clean energy technologies, while simultaneously addressing climate change and energy security concerns. ${ }^{4}$

A key question that emerges from this backdrop is how politics affect clean energy transitions. Broadly speaking, governments have adopted two, interrelated, approaches to promoting clean energy transitions. Top-down efforts have seen national governments engage in international negotiations on climate mitigation, such as under the United Nations (UN) or in the European Union, leading them to adopt policies that begin to transform their energy sectors. In bottom-up efforts, governments have sought foremost to negotiate changes to national energy and climate policies with domestic interest groups, before aggregating these into global agreements. The Paris Agreement of 2015 has given primacy to the second of these approaches. ${ }^{5}$

This article contends that we need to understand the effects of global interdependence on clean energy transitions, complementing research into top-down and bottom-up policymaking. ${ }^{6}$ Shifts in forms of interdependence between firms-influenced by the rise of global supply chains (GSCs) and China-have new implications for policy choices made by governments. Governments face more complex demands from domestic industries facing global economic competition, and act strategically in response to the actions of other governments and firms in the global economy. ${ }^{7}$ Also, industrial policies designed and

1 Clean energy technologies included in the calculation are renewable and nuclear power generation, renewable energy for transport and heat, and energy efficiency. Fossil fuel investments include upstream and downstream investments in oil and natural gas, coal mining and infrastructure, and coal, gas, and oil power generation. Investment in electricity networks is excluded from the calculation as services both fossil fuel and renewable electricity sources (IEA (2018), 26).

2 Rodrik (2014); Harrison et al. (2017).

3 Scherer (1992); Tyson (1992).

4 Aggarwal and Evenett (2012); Jaffe (2018).

5 Jordan et al. (2015); Bodansky (2016).

6 Farrell and Newman (2014).

7 The terms global supply chain, global value chain, global production network, global commodity network, and others, have been used across different disciplines to describe a broadly similar 
implemented by sub-national bodies such as energy ministries have important effects for governments and companies transnationally. Interdependence through economic and policy competition is thus a defining feature of clean energy transitions, in addition to purely cooperative outcomes that result from transnational interdependence in climate governance. ${ }^{8}$ The importance of new patterns of interdependence between governments and firms has increased given the focus of the Paris Agreement on bottom-up forms of international cooperation.

We pay particular attention to the effect of interdependence on green industrial policy. Industrial policies, which are defined as government policies that seek to promote decarbonization while promoting national economic advantage, are crucial to clean energy transitions. First, firms underinvest in clean technologies due to knowledge spillovers and other kinds of market failure, which makes a case for government investment. Second, prices do not internalize the local and global environmental effects of fossil fuels, suggesting a role for government intervention through industrial policy. ${ }^{9}$ Business actors are also central to decarbonizing energy systems investing in new low-carbon industries, and facing the prospect of managing the transition away from carbon-intensive fuels.

New forms of interdependence also have important implications for economic and environmental outcomes. Economically, the rise of GSCs offers an opportunity for companies in developing and middle-income countries to capture the value associated with the development of clean energy technologies through industrial upgrading. ${ }^{10}$ On the one hand, complementarities in innovation can emerge between companies in different countries. On the other, the globalization of innovation systems also presents challenges for first movers in clean energy technologies, which are often advanced industrialized countries, to maintain competitive advantage, as GSCs lower the barriers for market entry. Environmentally, interdependence matters because it influences the cost of clean energy technologies as well as the technology choices that companies make through temporal processes of lock-in, both of which affect the pace of the diffusion of clean energy technologies.

The remainder of this article proceeds as follows. First, we review the existing literature on clean energy transitions and lay out an interdependence perspective.

phenomenon in which productive processes are segmented and relocated across both firm and national boundaries. For a discussion, including regarding measurement, see Sturgeon et al. (2013).

8 Andonova (2009); Bulkeley et al. (2014).

9 Rodrik (2014).

10 Humphrey and Schmitz (2002); Zhang and Gallagher (2016). 
Second, we discuss firm/market interdependence and policy interdependence, drawing broadly from cases in the literature. Third, we examine how interdependence plays out in distinct mechanisms over time, including feedback and sequencing. Throughout we relate the articles of this special issue to the analytical themes discussed. The final section summarizes the article and discusses the economic and environmental implications of interdependence in clean energy.

\section{Clean energy transitions in a global economy}

Transforming the energy sector involves technological, economic, and social changes across multiple dimensions. ${ }^{11}$ It is a form of large-scale structural economic change. Given the distributive implications of policies, politics affects both the ambition of clean energy efforts, and the choice of policy instruments used to promote clean energy transitions in important ways.

The relationship between global and national efforts to promote clean energy transitions has changed over time. In 1997 the Kyoto Protocol established national targets and timetables for industrialized states to reduce carbon emissions relative to a baseline. The top-down narrative focused on multilateral climate mitigation bargaining, in forums such as the UN or the European Union, and led countries to adopt policies that transformed their energy sectors. The pledge-and-review process agreed to in the 2015 Paris Agreement focuses instead on national pledges that are reviewed and updated every five years. The agreement thus reflects the de facto recognition of the primacy of domestic over international climate and clean energy politics. ${ }^{12}$ This bottom-up perspective suggests that national policy choices aggregate to global commitments. ${ }^{13}$ Analytically, the bottom-up approach mirrors that of an open economy politics approach ${ }^{14}$ in which government policies emerge from bargaining between domestic interest groups. Outcomes of international agreements are then determined by negotiations between governments. Reflecting this, numerous studies of climate and clean energy transitions focus on domestic processes of interest formation and bargaining. ${ }^{15}$

However, while domestic politics remain crucial, we suggest that both governments and organized interests negotiate and implement policies supporting clean

11 Geels (2017).

12 Bodansky (2016).

13 Victor et al. (2005); Sabel and Victor (2015).

14 Lake (2009).

15 Hochstetler and Kostka (2015); Stokes (2015); Meckling and Nahm (2018). 
energy transitions under conditions of increasing global interdependence. ${ }^{16}$ Further, while decisions made by governments and firms have long been affected by choices made in other jurisdictions, we propose that the depth and complexity of independence places policymakers and managers in a qualitatively different environment. In developing an interdependence perspective on clean energy transitions, we draw on the new interdependence approach in comparative and international political economy. ${ }^{17}$ This approach and our adaptation are new for both theoretical and empirical reasons. Theoretically, the new interdependence approach extends early work on interdependence by identifying the causal mechanisms through which interdependence affects policy processes. ${ }^{18}$ In this article, we engage specifically with feedback and sequencing mechanisms. Empirically, we suggest that the "second unbundling" of global production and trade through the rise of GSCs has altered economic interdependence. ${ }^{19}$ This has crucial implications for the influence of policies beyond national borders, including extraterritorial effects of policies and the role of sub-national actors in transnational policymaking.

Increasing global interdependence affects firm and government behavior through a variety of mechanisms, including cooperation, learning, imitation, and coercion. ${ }^{20}$ Research on climate policy shows how interdependence can promote new forms of cooperation through transnational climate governance mechanisms. Transnational climate governance refers to cooperation, involving sub-national and non-state actors, such as sub-national governments, non-governmental organizations, domestic regulatory agencies, firms, and others, that transcends national borders. ${ }^{21}$ Cooperation can take the form of information sharing, capacity building, and rule-setting towards a shared public goal. ${ }^{22}$ Domestic factors, such as levels of wealth, the structure of political institutions, and the positions adopted by home governments towards climate change, also affect the extent to which cooperation occurs transnationally, including in clean energy technologies. ${ }^{23}$

Clean energy transitions are also characterized by competitive dynamics. For instance, falling solar photovoltaics (PV) module prices have been a key feature of the rapid reductions in solar system prices globally, and this is linked to the

16 Kern and Rogge (2016).

17 Farrell and Newman (2015).

18 Keohane and Nye (1977); Oatley (2011), 318; Farrell and Newman (2014), 344.

19 Baldwin (2016).

20 Elkins and Simmons (2004).

21 Andonova et al. (2009), 52.

22 Bäckstrand (2008).

23 Andonova et al. (2017). 
entrance of Chinese solar PV module manufacturers that developed enormous manufacturing capacity. ${ }^{24}$ Competitive dynamics can produce some forms of transnational cooperation. The setting of technology standards through intergovernmental and inter-firm coordination in the International Organization for Standardization, for example, lowers barriers to market entry while facilitating increased trade and investment in low-carbon technologies. ${ }^{25}$ Competitive dynamics, however, can also lead to an ongoing strategic interaction over time, as governments and companies seek to secure a durable competitive advantage in technologies involved in clean energy transitions.

Competitive dynamics are also affected by new forms of interdependence. Innovation systems underpinning clean energy transitions are increasingly globalized, for example, with implications for the investment decisions made by both firms and governments. ${ }^{26}$ The extraterritorial effects of clean energy policies can re-organize domestic industrial bargains, as firms and policymakers confront government policies and firm strategies from other jurisdictions. ${ }^{27}$ The magnitude and complexity of cross-national linkages today far exceed those that existed when governments and firms first sought to promote clean energy technologies after the oil crises of the 1970s. Policies implemented by governments in industrialized countries that create demand incentivize firms in emerging economies to enter the market to take advantage of the export opportunity. Interdependence creates new opportunities for industrial upgrading in developing countries, while presenting an opportunity for governments to affect firm behavior beyond their borders. ${ }^{28}$ Interdependence also creates new constraints for governments' abilities to create durable competitive advantages, as the barriers to market entry for new firms can be lowered.

A key task is to identify and describe the factors that lead to greater interdependence facing business and governments and to outline their implications for research and policy. In the next section, we discuss the factors deepening economic interdependence and their implications for both business demands for policy (section 3) and government supply of policy (section 4). The different factors are illustratively summarized in figure 1, and discussed in detail in sections 3 and 4 below. Figure 1 does not capture all forms of interdependence, but focuses on competitive interdependence and green industrial policies in particular.

24 Quitzow (2015); Schmidt and Huenteler (2016); Binz and Anadon (2018).

25 Potoski and Prakash (2005).

26 Binz et al. (2017); Binz and Truffer (2017); Nahm (2017).

27 Farrell and Newman (2015).

28 Crasnic et al. (2017). 


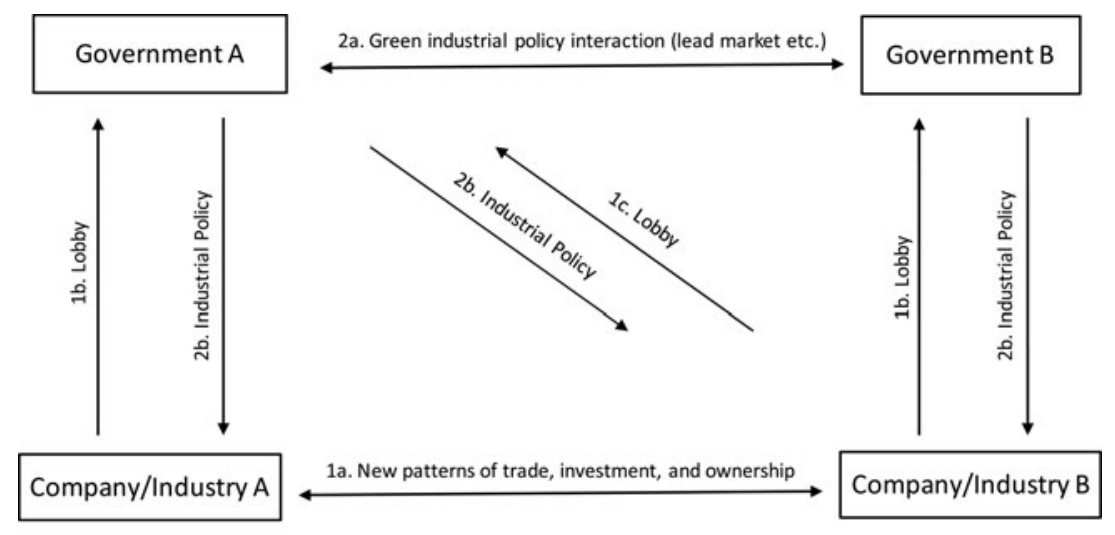

Note: 1 designates interdependent effects originating from company/industry activities; 2 designates effects from government activities

Figure 1: The New Interdependence and Clean Energy Transitions

\section{Business and interdependence}

New forms of economic interdependence are driven by a transformation in the opportunities available for business to trade and invest across borders. Changes in the organization of the production of clean energy technologies such as solar $\mathrm{PV}$, wind power, next-generation vehicles, and other low-carbon technologies, reflect a range of new opportunities for companies (effect 1a). The increased range of opportunities available to business is part of a broader transformation in the global structure of production of goods and services. Technological innovation enabling knowledge to be codified and transmitted across geographic and firm boundaries, and policy reforms reducing barriers to trade and investment, combined have enabled the vertical disintegration of supply chains. This means that larger shares of goods can be manufactured by companies specializing in specific stages of the production process. ${ }^{29}$ Data suggests that by the turn of the century up to 30 percent of world exports was already accounted for by vertical specialization across a broad range of industries. ${ }^{30}$ There is little reason to expect clean energy technologies to be insulated from the forces driving the emergence of GSCs in other industries, and empirical evidence is emerging that the organization of

29 OECD, WTO, and World Bank (2014); Gereffi et al. (2005).

30 Hummels, Ishii, and Yi (2001). 
production of goods and services in industries involved in clean energy transitions are also governed by GSCs. ${ }^{31}$

While the factors encouraging the rise of GSCs are widespread, China has played a particularly important role in the reorganization of the markets for technologies involved in clean energy transitions. ${ }^{32}$ China is important because of its increasing role as a supplier of intermediate and final products in low-carbon technologies, its rise as a source of demand for low-carbon technologies, and its increased significance as an investor in research, development, and deployment into low-carbon technologies. China represented 25 percent of total installed solar PV capacity in 2016, and 35 percent of global wind capacity in the same year. China also dominates other countries in terms of total deployment of battery electric vehicles. ${ }^{33}$ Moreover, China leads in terms of total investment in renewable energy, standing at US\$78.3 billion in 2016, ahead of the European Union at US\$59.8 billion, and the United States at US\$46.4 billion. Of this, China's spending on research and development stood at US\$2 billion, behind the European Union at US\$2.2 billion, but ahead of the United States at US\$1.5 billion. ${ }^{34}$ Chinese firms are also increasingly important in the supply of products. Additionally, China is estimated to have captured 44 percent of direct and indirect jobs in renewable energy outside large-scale hydropower, including 63 percent of jobs in solar PV, and 44 percent of jobs in wind power. ${ }^{35}$

GSCs are enabling companies involved in clean energy transitions to benefit from complementary capabilities elsewhere, supporting specialization, increased productivity, and the development of economies of scale (effect 1a). Firms located in developing countries can take advantage of the opportunities newly afforded by GSC participation to improve capabilities. While China continues to dominate, Steffen et al. (2018) note that the number of developing and middle-income countries with substantial investments in solar PV, wind power, and biomass, has grown markedly. Historically, knowledge has been more readily transmitted between

31 Data constraints create an important knowledge gap in the location of productive activities in clean energy technologies using this new form of industrial organization. Export statistics alone are not a reliable measure of the value added within a given jurisdiction, and the data used for inputoutput (IO) tables is partial (Sturgeon et al. (2013)). Importantly for clean technology industries, IO-related data is also collected at a comparatively high level of aggregation, meaning it does not provide information on value creation at a low-enough level of aggregation to provide a clear picture. Meckling and Hughes (2017); Nahm (2017).

32 Lewis (2013); Gallagher (2014).

33 REN21 (2017), 144, 166.

34 Ibid., 115-6.

35 Ibid., 43. 
organizations that are geographically proximate. ${ }^{36}$ Yet if we understand proximity as a social, in addition to a geographic, construct, ${ }^{37}$ interdependence that increases the social proximity of firms, as occurs through GSCs, enables innovation-related knowledge to disperse more readily than would occur in their absence. Consistent with this, GSCs have promoted the dispersion of innovative capabilities in the solar PV and wind industries. ${ }^{38}$ Chinese companies have used the participation in GSCs to develop skills in innovative manufacturing techniques in solar PV module and wind turbine technologies that complement capabilities in other markets. ${ }^{39}$ In the case of wind power, for example, licensing arrangements between Chinese, Danish, and German companies, along with the creation of joint ventures, amongst other mechanisms, have enabled the transfer of knowledge. ${ }^{40}$

The ability of firms to benefit from participation in GSCs for low-carbon technologies may vary by technology type. ${ }^{41}$ For example, German suppliers benefited from national policies more in the wind power sector than in solar PV. ${ }^{42}$ Biomass projects also continue to be dominated by domestic private project developers. ${ }^{43}$ In contrast, Chinese solar PV manufacturers emerged to dominate module production globally, but innovation rates in China in the wind turbines remain low, and Chinese manufacturers in export markets are uncompetitive. ${ }^{44}$ GSCs may also be less important in nationally bounded electricity grids. ${ }^{45}$ Traditional problems associated with grid access continue to hamper renewables development in China, for example, despite the success the country has had in building manufacturing capacity. ${ }^{46}$

The new interdependence through GSCs has two main implications for the demand side of policymaking, notably (1) business preferences and (2) the ability of business to organize collectively. First, changes in the global organization of production affects the types of demands organized interests make to governments (effect 1b). Policies supporting clean energy transitions have been shown to exhibit lock-in effects, as political interests seek to protect and expand the

36 Breschi and Malerba (2001).

37 Hansen and Coenen (2015).

38 Nahm (2017).

39 Nahm and Steinfeld (2014); Nahm (2017).

40 Quitzow et al. (2017).

41 Schmidt and Huenteler (2016).

42 Pegels and Lütkenhorst (2014).

43 Steffen et al. (2018).

44 Lam et al. (2017); Quitzow et al. (2017).

45 Richter (2013).

46 Moe (2015). 
benefits they receive from support policies. ${ }^{47}$ Such self-reinforcing dynamics of policies demand on collective action in clean energy industries. Yet the rise of GSCs can increase the heterogeneity and number of firms in an industry, which can translate into heterogeneity of policy preferences of business and undermine clean energy coalitions. As a result, governments may be subject to multiple claims by firms within an industry, creating challenging trade-offs for policymakers. ${ }^{48}$

Second, industry faces a coordination challenge in organizing new sets of interests. When industry-wide associations are unable to act in unison due to divisions in the policy preferences of their members, for example, this can lead to the creation of ad-hoc coalitions that coalesce around areas of common interest, as has been seen in legacy energy sectors. ${ }^{49}$ Certainly this has been a phenomenon in recent trade cases involving domestic claims by U.S. and EU firms in the solar PV industry, in which a series of ad-hoc coalitions were created in support of differing positions that companies adopted towards investigations into anti-dumping and anti-subsidy measures pursued by authorities in both jurisdictions. ${ }^{50}$ Chinese-owned producers also lobbied within Europe and the United States to oppose the imposition of barriers to trade $^{51}$ (effect 1c). These Chinese importers facilitated collective action among small and medium-sized project developers by providing financial support for ad hoc alliances opposing tariffs. In a similar vein, California-based solar leasing companies that emerged in the wake of early policy adoption in the state played important roles in organizing collective action in favor of renewable energy policy in other U.S. states. ${ }^{52}$ International project developers have also emerged as new and important private actors involved in the diffusion of renewable energy technologies globally, ${ }^{53}$ although the implications for interest group coordination remain an open question.

\section{Governments and interdependence}

Growing business interdependence not only affects business demands for policy, but also the supply of policy by governments. Interdependence through competition and trade has been shown to affect environmental regulation. For example, early regulatory movers with large market power can lead trading partners to

47 Meckling et al. (2015); Schmidt et al. (2017); Aklin and Urpelainen (2018).

48 Meckling and Hughes (2018).

49 Downie (2018).

50 Meckling and Hughes (2017).

51 Kolk and Curran (2015).

52 Stokes (2015).

53 Steffen et al. (2018). 
adopt their environmental standards. ${ }^{54}$ The distributive effects of industrial policies supporting clean energy transitions create, however, quite different political dynamics from environmental policy. ${ }^{55}$ Environmental regulations that impose concentrated costs on regulated industries, for example, can lead businesses that are disadvantaged to oppose such changes, even as they offer benefits to the public in the form of improved environmental quality. Governments may thus try to minimize the compliance cost for domestic industries. Environmental policy, such as carbon pricing and performance standards, matters significantly to the dynamics of clean energy transitions. Here we focus on green industrial policies that have been proliferating rapidly and are central to competitive interdependent dynamics. Industrial policies can provide concentrated benefits to targeted industries, while spreading the costs of the policy to taxpayers. Industry policies also have distributive effects for companies outside the national jurisdictions where they are applied. ${ }^{56}$ Governments compete to provide the greatest benefits to their domestic industries through measures such as subsidies and local content requirements, for example. The new interdependence in global production and innovation increases the extraterritorial effects of such green industrial policies.

Green industrial policy includes a range of policy instruments. We examine interdependence in green industrial policy choices related to demand-pull policies-policies targeted at reducing the cost of technologies to consumers, technology-push policies-policies that reduce the cost of technology innovation to firms, and trade policy. ${ }^{57}$ The "lead market" hypothesis has conventionally suggested that early movers that adopt demand-pull policies may secure a competitive advantage by developing domestic environmental technology industries. ${ }^{58}$ These industries can then export the environmental technology to late adopters of environmental regulations, which act as a demand pull for environmental technologies. ${ }^{59}$ In a similar vein, global competition in, for example, wind technology is found to lead to policy diffusion by lowering the cost of environmental technologies, thus reducing the cost of policy implementation in follower countries. ${ }^{60}$ While these arguments offer a rationale for unilateral environmental regulation, they simplify the interdependence among countries as one of regulatory diffusion. Yet a growing number of countries not only deploy environmental technologies

\footnotetext{
54 Vogel (1995).

55 Hughes and Urpelainen (2015).

56 Peters et al. (2012).

57 Nemet (2009).

58 Jänicke and Jacob (2004); Beise and Rennings (2005).

59 Busch and Jörgens (2005).

60 Hale and Urpelainen (2014); Meckling et al. (2017); Schmidt and Sewerin (2017).
} 
but also produce them. The rise of GSCs has lowered the barriers to market entry for vertically specialized firms, often from emerging economies. Their governments compete for global market share by employing industrial policy. These new interdependencies in global policy and technology development have led scholars to re-consider and revise the lead market model. ${ }^{61}$

Interdependence among producer countries conditions the choice of demand-side and technology-push policies by governments, along with firm strategies (effect 2a). In the development of the global electric vehicle (EV) industry, a set of interdependencies between industrialized countries, notably Japan and the United States, and an emerging economy, China, led to the global diffusion of the technology. California's Zero Emission Vehicle program and China's EV quota, both powerful demand-pull policies, have created a spillover effect in a number of advanced industrialized auto nations. Germany, France, and others began to provide EV-related technology-push policies for domestic automakers, along with demand-pull policies for domestic deployment. ${ }^{62}$ This led to the beginning globalization of the EV industry. The EV case shows how the rise of both GSCs and emerging economies led to new forms of cooperative and competitive interdependence. China, California, and other first movers were only able to enter EV manufacturing because they could import intermediate products, notably batteries, from Japan and South Korea, where initially all lithium-ion battery production was located. ${ }^{63}$ In addition, early movers such as California's Tesla also depended initially on demand for exports to other countries with strong demand-pull policies, such as Norway. Green industrial policy of government A thus offered an opportunity to domestic firms in country B (effect $2 \mathrm{~b}$ ). The adoption of bold green technology and industrial policies by emerging economies has also shifted patterns of global policy diffusion. In the EV industry, China's quotas for EV sales have had a global market-creating effect, incentivizing other governments to promote EV firms and technology deployment. This suggests a "China effect" rather than a California effect-in which emerging economies seeking industrial upgrading become the global pacesetters in policy. ${ }^{64}$ Green industrial policy in an emerging economy can thus present a threat to incumbent firms in industrialized countries.

61 Quitzow et al. (2014).

62 Bose Styczynski and Hughes (2018).

63 Lithium-ion batteries represent an additional form of interdependence, in this case through cross-sectoral spill-over, in which batteries designed for use in computer laptops and other uses were applied to the automotive sector. On spill-overs across end-product applications, see Battke and Schmidt (2015) and Schmidt et al. (2016).

64 Meckling and Nahm (forthcoming). 
Comparing policy evolution in the solar and EV sectors, Hughes and Meckling (2018) show in this special issue how variation in technological complexity leads to different types of interdependence in technology-push policies. In low-complexity technologies such as solar, market competition focuses on price, which incentivizes policymakers in follower countries to provide support for increasing domestic manufacturing capacity to achieve economies of scale and price advantages-a process of "scaling up." In high-complexity technologies such as EVs, market competition focuses on product differentiation, which incentivizes governments in follower countries to support research and development of domestic firms to produce differentiated products-a process of "innovating up."

Interdependence also conditions the choice of trade policy in clean energy industries. Trade policy has important implications for clean energy transitions. On the one hand, open trade can facilitate the rapid development and deployment of clean energy technologies by facilitating specialization and economies of scale, thus driving down technology cost. But it may challenge the domestic industrial bargains underpinning these technologies in lead markets. On the other hand, trade protection through tariff and non-tariff barriers may increase the relative cost of low-carbon technologies compared to conventional technologies, while possibly ensuring domestic political support for government investment in clean energy sectors. The rise of GSCs has lowered barriers for firms in emerging economies to enter global markets and intensified producer competition. This has led to the emergence of trade remedy disputes in the solar and wind sectors between mostly industrialized countries and emerging economies. ${ }^{65}$ Research shows that the extent to which firms are tied into GSCs affects their trade policy preferences, altering domestic clean energy technologies. In the solar case, differential levels of integration of U.S. and EU firms with Chinese solar firms led to competing "free trade" and "trade protection" coalitions in the two countries. ${ }^{66}$ This reflects broader findings in international political economy (IPE) on how interdependence through GSCs shifts trade preferences toward open trade. ${ }^{67}$

While we here focus on how different policy types affect interdependence, we acknowledge that domestic institutions mitigate these effects in at least two ways. First, domestic institutions affect what types of policies-such as research and development policy versus manufacturing support-countries are likely to be able to adopt. Domestic institutions also shape the responsiveness of countries to interdependence. ${ }^{68}$

65 Lewis (2014); Wu and Salzman (2014).

66 Hughes and Meckling (2017); Meckling and Hughes (2018).

67 Gawande et al. (2014).

68 Neumayer and Plümper (2012). 


\section{Interdependence over time}

The politics of decarbonizing energy systems are dominated by the problem of policy inertia due to the durability and returns to scale from existing fossil fuel technology systems. ${ }^{69}$ As a result, clean energy transitions are long-term processes of policy change. Concepts such as policy feedback and sequencing, developed in historical institutionalism, can be deployed to explain temporal dynamics in the context of national energy transitions ${ }^{70}$ and climate policy more broadly. ${ }^{71}$ Cross-national policy interdependence in clean energy transitions are also affected by temporal factors. In this section, we focus on policy feedback and sequencing dynamics, in particular, while drawing on the new interdependence approach. ${ }^{72}$

\section{Policy feedback}

Positive feedback occurs when "an action or choice creates positive externalities when that same choice is made by other people [...] little bonuses given to people who already made that choice or who will make that choice in the future." ${ }^{73}$ Positive feedback underpins lock-in into fossil fuel technologies, ${ }^{74}$ and the same dynamics are evident in clean energy transitions. Most obviously, renewable energy policies can create and expand interest groups that then go on to lobby for maintaining and extending those policies ${ }^{75}$ or to help destabilize policies supporting fossil fuel technologies, such as fossil fuel subsidies. ${ }^{76}$ In this issue, Aklin (2018) shows how stock market data suggest that the election of President Trump, a vocal critic of renewable energy, did not negatively affect the U.S. renewable energy industry, implying expectations of path dependency in policy support.

In a global context, such positive feedback dynamics can occur when green industrial policy in country A mobilizes and grows interest groups in country B in support of clean energy policy (cross-national feedback). For example, California's Zero Emission Vehicle program, which mandates automakers to offer EVs in California, and China's EV quota have mobilized pro-EV

69 Unruh (2000).

70 Biber (2013); Zysman and Huberty (2014); Stokes (2015); Lockwood et al. (2016); Meckling et al. (2017); Aklin and Urpelainen (2018).

71 Levin et al. (2012); Lockwood (2013); Jordan and Matt (2014).

72 Bach and Newman (2010); Farrell and Newman (2010).

73 Page (2006), 88.

74 Unruh (2000).

75 Aklin and Urpelainen (2013); Meckling et al. (2015).

76 Schmidt et al. (2017). 
constituencies in exporting auto countries such as France and Germany, which then lobbied for support for the development of domestic EV industries and EV deployment from their home governments. Interdependence through global trade has facilitated this cross-border policy reinforcement. Chineseowned companies have been found to lobby the U.S. government to reject trade barriers levied against China-based manufacturers. ${ }^{77}$ The temporal character of coalition creation also affects, and is affected by, choices made in other states. Thus, the development of battery EV technologies in the United States and Japan spurred the creation of coalitions in support of this new technology in China, as well as in countries such as Norway and the Netherlands that do not have domestic automotive producers.

Positive feedback also exists between domestic clean energy policies and international climate policy (multi-level feedback). As governments invest increasingly in clean energy, and domestic coalitions for clean energy expand, governments may be willing to commit to greater emission reductions in international negotiations. If such processes occur in a sufficient number of negotiating parties, this could lead to a positive spiral of strengthening international institutions. ${ }^{78}$ Similarly, early investments by a few countries into clean energy technologies can reduce the cost of technologies, ${ }^{79}$ and thus adjustment costs for follower countries. This increases the likeliness that follower countries adopt clean energy and climate policies, which supports international cooperation on climate change. ${ }^{80}$ Kelsey (2018), in this special issue, shows that the likeliness of the emergence of policy feedback on firm interests depends significantly on the type of industry. Specifically, the ease of technological substitutability in a polluting industry matters to the extent to which the industry can transform and begins to support international environmental policy.

\section{Relative sequencing}

A second type of temporal process in clean energy transitions that is affected by increasing interdependence is relative sequencing, defined as temporally ordered and causally connected events. ${ }^{81}$ While processes of positive feedback are path dependent, in that earlier events increase the likelihood that similar practices are reproduced, relative sequencing see latter choices conditioned by earlier

77 Kolk and Curran (2017).

78 Kelsey (2014).

79 Meckling et al. (2017); Schmidt and Sewerin (2017).

80 Kim and Urpelainen (2013); Meckling (2018).

81 Mahoney (2000), 509. 
events, but without any expectation that an earlier policy or institution will be reproduced, and there is thus no expectation of lock-in. ${ }^{82}$

There are multiple examples of relative sequencing in global clean energy transitions. As Breetz et al. (2018) point out, initial investments in a technology in its pre-commercialization phase require a particular constellation of actors. As products shifted towards commercialization and enter a phase in which scale economics is an important driver of falling prices, however, the political coalitions required to maintain clean energy technologies begin to change, and indeed, must become more robust if they are to defend against political coalitions supporting legacy technologies. Given the significant variation in national innovation systems, different countries may play different roles over the course of innovation cycle. ${ }^{83}$

Latter patterns of coalition building and interest group politics are thus dependent on earlier decisions, but do not replicate them in form. For example, in the development of the global solar industry, a set of interdependencies between an industrialized country, Germany, and an emerging economy, China, led to cross-national sequencing that promoted the globalization of the industry. ${ }^{84}$ When the industry first emerged, it was organized as three distinct regional economies in Europe, Japan, and the United States. But the creation of Germany's feedin tariff, a powerful demand-pull policy, created a spillover effect in China, as Chinese firms started producing solar modules for the German market, backed by policies implemented by the Chinese government. GSCs for solar PV emerged that incorporated a mix of vertically specialized and vertically integrated firms spanning Europe, the United States, Japan, and elsewhere. Feed-in tariffs thus mobilized and grew renewable energy constituencies across countries, notably in China. They also negatively affected a number of U.S.-based manufacturers not participating in GSCs that appealed for, and received, trade relief. The Chinese government then responded by implementing trade remedies initially focused on upstream ingot producers in the case of the United States, in an attempt to shift sentiment in the United States. The creation of a durable and successful policy targeting demand for solar PV in Germany thus led to a process of relative sequencing in which Chinese manufacturers entered the market, leading to a different response using the instrument of trade policy in both Europe and the United States.

Market developments in solar PV demonstrate also that feedback processes and sequencing can occur simultaneously. The German Ministry of

82 Howlett (2009).

83 See also, Fankhauser et al. (2013).

84 Hoppmann et al. (2014); Quitzow (2015). 
Environment played a key role in shaping the policy preferences of late-movers, in terms of sectoral choices about where to invest. While first-mover advantages accrued to firms investing in the markets, however, this drew investments from Chinese producers of solar PV modules for export purposes. This highlights a broader point: that under conditions of interdependence, governments and firms can create lead markets may be able to create path-dependent processes around particular technology pathways, but processes of sequencing mean the first-mover advantage they initially enjoy may be ephemeral, depending on the capabilities of follower firms and governments, and the reactions of home governments to new market entry by firms located in other jurisdictions. ${ }^{85}$

\section{Conclusion and implications}

The 2015 Paris Agreement on Climate Change recognizes that multilateral cooperation is only possible when national governments have negotiated agreements with domestic interests. While this places increased weight on the importance of understanding the domestic politics of climate change, in this article we have proposed that increased interdependence influences policymaking across national jurisdictions. Governments and firms face new opportunities and constraints in negotiating policy domestically due to profound changes in the organization of the global production of clean energy technologies. In particular, the rise of global supply chains and growing extraterritorial effects of industrial policy shape patterns of interdependence. In contrast to notions of cooperation that inform patterns of transnational climate governance, we noted that interdependence in clean energy transitions is characterized by competitive dynamics that may or may not lead to cooperative outcomes.

We have suggested that the new interdependence literature offers conceptual tools to examine the changed environment facing governments and firms in clean energy transitions. In particular, it points to the importance of identifying specific pathways through which interdependence is expressed. We have outlined the forces that constitute the new forms of interdependence in clean energy transitions, categorizing them into changes in the organization of production that affect firm and government choices, and the increased ability of (sub-)national governments to change the preferences of actors in other national jurisdictions. GSCs in particular present companies with a new set of choices about where to locate production, and whether they should specialize vertically, or integrate across multiple stages of the supply chain. China has been central to this

85 Bach and Newman (2010), 672; Farrell and Newman (2010). 
process, emerging as an important production location for components used in clean energy products, as well as an increasingly important source of demand in its own right. Steffen et al. (2018) detail the increasing role of other developing and middle-income countries in renewable energy development. They also identify the role a new private actor-the international private project developer-has played in facilitating the diffusion of renewable energy to an increasing number of developing countries.

We also emphasized how temporal dynamics of feedback and sequencing across countries shape patterns of clean energy transitions. In this special issue, Aklin shows how the U.S. renewables industry is resilient to electoral shocks, suggesting domestic path dependency in policy support. Kelsey demonstrates that the likeliness of policy feedback between national and international environmental policy depends on how easily dirty technologies can be substituted by clean technologies. Breetz et al. suggest that comparative institutional advantages allow countries to play different roles in the innovation cycle, showing the importance of cross-national sequencing. Hughes and Meckling demonstrate how the complexity of technologies conditions what kinds of policies follower countries in green industries are likely to adopt.

This volume suggests an important research agenda on global interdependence in clean energy transitions, and its implications for institutional change and policy outcomes. We highlight in particular three promising avenues: the drivers of business interdependence, the effects of different industrial policy instruments, and the role of domestic institutions.

First, the extent to which interdependence needs to move into the focus of analysis is ultimately an empirical question. ${ }^{86}$ For some questions on clean energy transitions a bottom-up analysis may be appropriate, while in others analyzing interdependence is key. The nature and extent of interdependence varies in particular across sectors and technologies. Industries such as the automotive industry are different in terms of transnational interdependent linkages compared to the power sector, for example. In this issue Steffen et al. (2018) note, for example, the different degree to which global developers matter in solar PV and wind, relative to biomass projects. This raises questions about the factors shaping the rise of supply chains and different supply chain structures across technologies.

Second, industrial policies are made up of a wide variety of different policy instruments that have different distributive effects. The differences in the distributive effects of these policies can, in turn, bring about different transnational dynamics between governments, and between governments and firms. For example, financial incentives designed to create demand for renewable energy

86 Chaudoin et al. (2014). 
have thus quite different effects on the behaviors of governments and firms transnationally, compared to research and development subsidies or regulatory measures. What types of effects do different industrial policy instruments have on foreign firms and governments?

Third, domestic institutions may mitigate the effects of economic interdependence on domestic politics ${ }^{87}$ and shape comparative advantages in clean energy innovation and production. What types of institutions matter and how do they mitigate interdependence? For instance, political competition in business-government relations has been shown to allow global technological change to affect domestic industrial policies more immediately than under conditions of political coordination. ${ }^{88}$

Improving our understanding of global interdependence in clean energy transitions matters for both economic and environmental reasons. Economically, new forms of interdependence affect the ability of firms to capture value in globalized industries. On the one hand, the depth of interdependence raises questions for first movers about the durability of any competitive advantage they may secure. New interdependence through GSCs offers a further opportunity for firms in developing and middle-income countries to enter new global industries in clean energy technologies. Governments in these countries can also use local content requirements, joint venture regulations, or other arrangements to promote GSC participation and industrial upgrading in technologies related to clean energy transitions. The rise of developing country competitors obviously raises issues for governments in advanced industrialized countries whether GSCs affect their ability to implement policies that create durable competitive advantage for domestic industries (effect $2 b)$. A conceit of new green industry policy is that the benefits associated with public investments will be captured domestically in the form of employment opportunities, returns on intellectual property, or other benefits. Yet policies that create demand can draw in production located in other jurisdictions. Even when branded locally, components of final products may be made up of inputs sourced from vertically specialized firms located in other jurisdictions (effect 1a). The economic benefits of policies thus may not be captured within national economies, although this effect may once again be technology dependent, with similar dynamics not yet evident in electric vehicles. ${ }^{89}$

New interdependencies also have potential environmental implications. On the one hand, feedback dynamics that facilitate the more rapid deployment of a particular technology can lock in potentially sub-optimal technologies globally.

87 Neumayer and Plümper (2012).

88 Meckling and Nahm (2018).

89 Hughes and Meckling (2018). 
For example, the global diffusion of polycrystalline solar cells may limit opportunities for more advanced technologies to enter the market. ${ }^{90}$ In a similar vein, the expansion of the global production of lithium-ion batteries for EVs may create barriers for more advanced battery technologies to enter the market, although the likelihood of lock-in is also conditioned by the number of end-use technologies. ${ }^{91}$ On the other hand, the ability of firms to vertically specialize key parts of productive processes potentially enables greater specialization, increases productivity, and allows clean energy industries to take advantage of economies of scale. As we have seen in solar PV and batteries, this has enabled new, low-carbon technologies to more rapidly compete against legacy fossil fuels, hastening the transition to clean power systems.

\section{References}

Aggarwal, V. K., and S. J. Evenett. 2012. "Industrial policy choice during the crisis era." Oxford Review of Economic Policy 28 (2): 261-83.

Aklin, M., and J. Urpelainen. 2013. "Political competition, path dependence, and the strategy of sustainable energy transitions." American Journal of Political Science 57 (3): 643-58.

Aklin, M. 2018. "How robust is the renewable energy industry to political shocks? Evidence from the 2016 U.S. elections?" Business and Politics 20 (4): 523-52.

Aklin, M., and J. Urpelainen. 2018. Renewables: The Politics of a Global Energy Transition. Cambridge, MA: MIT Press.

Andonova, L. B., et al. 2009. "Transnational Climate Governance." Global Environmental Politics 9 (2): 52-73.

Andonova, L. B., et al. 2017. "National Policy and Transnational Governance of Climate Change: Substitutes or Complements?” International Studies Quarterly 61 (2): 253-68.

Andonova, L. B., M. M. Betsill, and H. Bulkeley. 2009. "Transnational climate governance.” Global environmental politics 9 (2): 52-73.

Bach, D., and A. L. Newman. 2010. "Governing lipitor and lipstick: Capacity, sequencing, and power in international pharmaceutical and cosmetics regulation." Review of international Political Economy 17 (4): 665-95.

Bäckstrand, K. 2008. "Accountability of networked climate governance: The rise of transnational climate partnerships." Global environmental politics 8 (3): 74-102.

Baldwin, R. 2016. The Great Convergence: Information Technology and the New Globalization. Cambridge, MA: Harvard University Press.

Battke, B., and T. S. Schmidt. 2015. "Cost-efficient demand-pull policies for multi-purpose technologies-The case of stationary electricity storage." Applied Energy 155: 334-48.

Beise, M., and K. Rennings. 2005. "Lead markets and regulation: a framework for analyzing the international diffusion of environmental innovations." Ecological Economics 52 (1): 5-17.

90 Sivaram (2018).

91 Schmidt et al. (2016). 
Biber, E. 2013. “Cultivating a Green Political Landscape.” Vanderbilt Law Review 66 (2): 399-462.

Binz, C., and B. Truffer. 2017. "Global Innovation Systems-A conceptual framework for innovation dynamics in transnational contexts." Research Policy 46 (7): 1284-98.

Binz, C., et al. 2017. "Spatial lifecycles of cleantech industries-The global development history of solar photovoltaics." Energy Policy 101: 386-402.

Binz, C., and L. D. Anadon. 2018. "Unrelated diversification in latecomer contexts: Emergence of the Chinese solar photovoltaics industry." Energy Policy 28: 13-34.

Bodansky, D. 2016. “The Paris climate change agreement: a new hope?" American Journal of International Law 110 (2): 288-319.

Bose Styczynski, A., and L. Hughes. 2018. "A cross-national comparison of electric vehicle and fuel cell vehicle industry policies." Environmental Innovation and Societal Transitions. https://doi. org/10.1016/j.eist.2018.09.002

Breetz, H., M. Mildenberger, and L. Stokes. 2018. "The political logics of clean energy transitions." Business and Politics 20 (4): 492-522.

Breschi, S., and F. Malerba. 2001. "The geography of innovation and economic clustering: some introductory notes." Industrial and corporate change 10 (4): 817-33.

Bulkeley, H., L. Andonova, K. Bäckstrand, M. Betsill, D. Compagnon, T. Hale, M. Hoffmann, P. Newell, M. Paterson, C. Roger, and S. VanDeveer. 2014. Transnational Climate Governance. Cambridge, United Kingdom: Cambridge University Press.

Busch, P.-O., and H. Jörgens. 2005. "The International Sources of Policy Convergence. Explaining the Spread of Environmental Policy Innovations." Journal of European Public Policy 12 (5): 860-84.

Chaudoin, S., et al. 2014. "International Systems and Domestic Politics: Linking Complex Interactions with Empirical Models in International Relations." International Organization 69 (2): 275-309.

Crasnic, L., et al. 2017. "Networked liabilities: Transnational authority in a world of transnational business." European Journal of International Relations 23 (4): 906-29.

Curran, L. 2015. "The impact of trade policy on global production networks: The solar panel case." Review of International Political Economy 22 (5): 1025-054.

Downie, C. 2018. "Ad hoc coalitions in the United States energy sector: case studies in the gas, oil, and coal industries." Business and Politics 20 (4): 643-68.

Elkins, Z., and B. Simmons. 2004. "On Waves, Clusters, and Diffusion: A Conceptual Framework." The Annals of the American Academy 598 (1): 33-51.

Fankhauser, S., et al. 2013. "Who will win the green race? In search of environmental competitiveness and innovation." Global Environmental Change 23 (5): 902-13.

Farrell, H., and A. L. Newman. 2010. "Making global markets: Historical institutionalism in international political economy." Review of international Political Economy 17 (4): 609-38.

Farrell, H., and A. L. Newman. 2014. "Domestic Institutions beyond the Nation-State: Charting the New Interdependence Approach.” World Politics 66 (2): 331-63.

Farrell, H. and A. Newman. 2015. "The New Politics of Interdependence: Cross-National Layering in Trans-Atlantic Regulatory Disputes.” Comparative Political Studies 48 (4): 497-526.

Gallagher, K. S. 2014. The globalization of clean energy technology: Lessons from China. Cambridge, MA: MIT Press.

Gawande, K., et al. 2014. "Global Supply Chains and Trade Policy Responses to the 2008 Crisis." The World Bank Economic Review 29 (1): 102-28.

Geels, F. W. 2017. "Sociotechnical transitions for deep decarbonization." Science 357 (6357): 1242-44. 
Gereffi, G., et al. 2005. "The governance of global value chains.” Review of international Political Economy 12 (1): 78-104.

Hale, T., and J. Urpelainen. 2014. "When and how can unilateral policies promote the international diffusion of environmental policies and clean technology?" Journal of Theoretical Politics 27 (2): 177-205.

Hansen, T., and Coenen, L. 2015. "The geography of sustainability transitions: Review, synthesis and reflections on an emergent research field." Environmental innovation and societal transitions 17: 92-109.

Harrison, A., L. A. Martin, and S. Nataraj. 2017. "Green Industrial Policy in Emerging Markets." Annual Review of Resource Economics 9: 256-74.

Hochstetler, K., and G. Kostka. 2015. "Wind and Solar Power in Brazil and China: Interests, StateBusiness Relations, and Policy Outcomes.” Global Environmental Politics 15 (3): 74-94.

Hoppmann, J., et al. 2014. "Compulsive policy-making-The evolution of the German feed-in tariff system for solar photovoltaic power." Research Policy 43 (8): 1422-41.

Howlett, M. 2009. "Process sequencing policy dynamics: Beyond homeostasis and path dependency." Journal of Public Policy 29 (3): 241-62.

Hughes, L., and J. Meckling. 2017. "The politics of renewable energy trade: The US-China solar dispute." Energy Policy 105: 256-62.

Hughes, L., and J. Meckling. 2018. "Policy competition in clean technology: Scaling up or innovating up?" Business and Politics 20 (4): 588-614.

Hughes, L., and J. Urpelainen. 2015. "Interests, institutions, and climate policy: Explaining the choice of policy instruments for the energy sector." Environmental Science \& Policy 54: 52-63.

Humphrey, J., and H. Schmitz. 2002. "How does insertion in global value chains affect upgrading in industrial clusters?” Regional Studies 36 (9): 1017-1027.

Hummels, D., Ishii, J. and Yi, K.M. 2001. "The nature and growth of vertical specialization in world trade." Journal of international Economics (54) (1): 75-96.

International Energy Agency. 2018. World Energy Investment Report. Paris: IEA.

Jaffe, A. M. 2018. "Green Giant: Renewable Energy and Chinese Power." Foreign Affairs (March/ April): 83-93.

Jänicke, M., and K. Jacob. 2004. "Lead Markets for Environmental Innovations: A New Role for the Nation State.” Global Environmental Politics 4 (1): 29-46.

Jordan, A., and E. Matt. 2014. "Designing policies that intentionally stick: policy feedback in a changing climate." Policy Sciences 47 (3): 227-47.

Jordan, A. J., D. Huitema, M. Hildén, H. Van Asselt, T. J. Rayner, J. J. Schoenefeld, J. Tosun, J. Forster, and E. L. Boasson. 2015. "Emergence of polycentric climate governance and its future prospects." Nature Climate Change 5 (11): 977.

Kelsey, N. 2014. The Green Spiral: Policy-Industry Feedback and the Success of International Environmental Negotiation. Berkeley, CA: University of California, Berkeley.

Kelsey, N. 2018. "Industry Type and Environmental Policy: Industry Characteristics Shape the Potential for Success in International and National Climate Policy." Business and Politics 20 (4): 615-42.

Keohane, R., and J. Nye. 1977. "Power and Interdependence Boston, Little, Brown.

Kern, F., and K. S. Rogge. 2016. "The pace of governed energy transitions: Agency, international dynamics and the global Paris agreement accelerating decarbonisation processes?" Energy Research \& Social Science 22: 13-17. 
Kim, S. E., and J. Urpelainen. 2013. "Technology Competition and International Co-operation: Friends or Foes?" British Journal of Political Science 44 (3): 545-74.

Kolk, A. and L. Curran. 2017. "Contesting a place in the sun: on ideologies in foreign markets and liabilities of origin." Journal of Business Ethics 142 (4): 697-717.

Kolk, A., and L. Curran. 2015. "Contesting a Place in the Sun: On Ideologies in Foreign Markets and Liabilities of Origin." Journal of Business Ethics 142 (4): 697-717.

Lake, D. A. 2009. "Open economy politics: A critical review." The Review of International Organizations 4 (3): 219-44.

Lam, L.T., L. Branstetter and I.M Azevedo 2017. “China's wind industry: Leading in deployment, lagging in innovation.” Energy Policy 106: 588-599.

Levin, K., et al. 2012. "Overcoming the tragedy of super-wicked problems: constraining our future selves to ameliorate global climate change." Policy Sciences 45: 123-52.

Lewis, J. I. 2013. Green innovation in China: China's wind power industry and the global transition to a low-carbon economy. New York: Columbia University Press.

Lewis, J. I. 2014. "The Rise of Renewable Energy Protectionism: Emerging Trade Conflicts and Implications for Low-carbon Development." Global Environmental Politics 14 (4): 10-35.

Lockwood, M. 2013. "The political sustainability of climate policy: The case of the UK Climate Change Act.” Global Environmental Change 23 (5): 1339-48.

Lockwood, M., et al. 2016. "Historical institutionalism and the politics of sustainable energy transitions: A research agenda." Environment and Planning C: Government and Policy 35 (2): 1-22.

Mahoney, J. 2000. "Path Dependence in Historical Sociology." Theory and Society 29 (4): 507-48.

Meckling, J. 2018. "The developmental state in global regulation: Economic change and climate policy." European Journal of International Relations 28 (1): 58-81.

Meckling, J., and J. Nahm. 2018. "When do states disrupt industries? Electric cars in Germany and the United States." Review of international Political Economy 25 (4): 505-29.

Meckling, J., and J. Nahm. Forthcoming. "Banning dirty cars: Political signaling and green technology competition.” Energy Policy.

Meckling, J., and L. Hughes. 2017. "Globalizing Solar: Global Supply Chains and Trade Preferences.” International Studies Quarterly 61: 225-235.

Meckling, J., and L. Hughes. 2018. "Protecting Solar: Global Supply Chains and Business Power." New Political Economy 23 (1): 88-104.

Meckling, J., et al. 2015. "Winning Coalitions for Climate Policy: Green Industrial Policy Builds Support for Carbon Regulation." Science 249 (6253): 1170-71.

Meckling, J., et al. 2017. "Policy sequencing toward decarbonization." Nature Energy 2: 918-922.

Moe, E. 2015. Renewable Energy Transformation or Fossil Fuel Backlash: Vested Interests in the Political Economy. New York: Palgrave Macmillan.

Nahm, J. 2017. "Renewable futures and industrial legacies: Wind and solar sectors in China, Germany, and the United States." Business and Politics 19 (1): 68-106.

Nahm, J., and E. S. Steinfeld. 2014. "Scale-up Nation: China's Specialization in Innovative Manufacturing." World Development 54: 288-300.

Nemet, G. F. 2009. "Demand-pull, technology-push, and government-led incentives for non-incremental technical change." Research Policy 38 (5): 700-709.

Neumayer, E., and T. Plümper. 2012. "Conditional spatial policy dependence: theory and model specification.” Comparative Political Studies 45.7 (2012): 819-49.

Oatley, T. 2011. "The Reductionist Gamble: Open Economy Politics in the Global Economy." International Organization 65 (2): 311-41. 
OECD, WTO, and World Bank. 2014. "Global Value Chains: Challenges, Opportunities, and Implications for Policy." Report preparted for submission to the G20 Trade Ministers Meeting, Sydney Australia, 19 July 2014. Available at: http://www.oecd.org/tad/gvc_report_g20_july_ 2014.pdf (accessed 25 October, 2018)

Page, S. E. 2006. "Path Dependence." Quarterly Journal of Political Science 1 (1): 87-115.

Pegels, A., and W. Lütkenhorst. 2014. "Is Germany's energy transition a case of successful green industrial policy? Contrasting wind and solar PV.” Energy Policy 74: 522-534.

Peters, M., M. Schneider, T. Griesshaber, and V. H. Hoffmann. 2012. "The impact of technologypush and demand-pull policies on technical change-Does the locus of policies matter?" Research Policy 41 (8): 1296-308.

Potoski, M., and A. Prakash. 2005. “Green Clubs and Voluntary Governance: ISO 14001 and Firms' Regulatory Compliance.” American Journal of Political Science 49 (2): 235-48.

Quitzow, R. 2015. "Dynamics of a policy-driven market: The co-evolution of technological innovation systems for solar photovoltaics in China and Germany." Environmental Innovation and Societal Transitions 17: 126-48.

Quitzow, R., R. Walz, J. Köhler, and K. Rennings. 2014. “The concept of “lead markets” revisited: Contribution to environmental innovation theory." Environmental Innovation and Societal Transitions 10: 4-19.

Quitzow, R., J. Huenteler, and H. Asmussen. 2017. “Development trajectories in China's wind and solar energy industries: How technology-related differences shape the dynamics of industry localization and catching up." Journal of Cleaner Production 158: 122-33.

REN21. 2017. Renewable 2017: Global Status Report. Paris: Renewable Energy Policy Network for the 21st Century.

Richter, M. 2013. "Business model innovation for sustainable energy: German utilities and renewable energy." Energy Policy 62: 1226-37.

Rodrik, D. 2014. "Green industrial policy." Oxford Review of Economic Policy 30 (3): 469-91.

Sabel, C. F., and D. G. Victor. 2015. "Governing global problems under uncertainty: making bottom-up climate policy work." Climatic Change 144 (1): 15-27.

Scherer, F. M. 1992. International High-Technology Competition. Cambridge, MA: Harvard University Press.

Schmidt, T. S., and J. Huenteler. 2016. "Anticipating industry localization effects of clean technology deployment policies in developing countries." Global Environmental Change 38: $8-20$.

Schmidt, T. S., B. Battke, D. Grosspietsch, and V. H. Hoffmann. 2016. "Do deployment policies pick technologies by (not) picking applications?-A simulation of investment decisions in technologies with multiple applications." Research Policy 45 (10): 1965-83.

Schmidt, T. S., T. Matsuo, and A. Michaelowa. 2017. "Renewable energy policy as an enabler of fossil fuel subsidy reform? Applying a socio-technical perspective to the cases of South Africa and Tunisia." Global Environmental Change, 45: 99-110.

Schmidt, T. S., and S. Sewerin. 2017. "Technology as a driver of climate and energy politics." Nature Energy 2: 17084.

Sivaram, V. 2018. Taming the Sun: Innovation to Harness Solar Energy and Power the Planet. Cambridge, MA: MIT Press.

Steffen, B., T. Matsuo, D. Steinemann, and T. Schmidt. 2018. “Opening new markets for clean energy: The role of project developers in the global diffusion of renewable energy technologies." Business and Politics 20 (4): 553-87. 
Stokes, L. C. 2015. Power Politics: Renewable Energy Policy Change in US States. Cambridge, MA: MIT Press.

Sturgeon, T. J., P. B. Nielsen, G. Linden, G. Gereffi, and C. Brown. 2013. “Direct Measurement of Global Value Chains: Collecting Product- and Firm-Level Statistics on Value Added and Business Function Outsourcing and Offshoring." In Trade in Value Added: Developing New Measures of Cross-Border Trade, edited by A. Mattoo, Z. Wang, and S.-J. Wei. Washington, D.C.: The World Bank, 289-319.

Tyson, L. D. A. 1992. "Who's Bashing Whom? Trade Conflict in High-Technology Industries." Washington, D.C.: Institute for International Economics.

Unruh, G. C. 2000. “Understanding Carbon Lock-in.” Energy Policy 28: 817-30.

Victor, D. G., et al. 2005. “A Madisonian Approach to Climate Policy.” Science 16 (5742): 1820-21.

Vogel, D. 1995. Trading Up. Consumer and Environmental Regulation in a Global Economy. Cambridge, MA: Harvard University Press.

Wu, M., and J. Salzman. 2014. "The Next Generation of Trade and Environment Disputes: The Rise of Green Industrial Policy.” Northwestern University Law Review 108 (2): 401-74.

Zhang, F., and Gallagher, K. S. 2016. "Innovation and technology transfer through global value chains: Evidence from China's PV industry.” Energy Policy 94: 191-203.

Zysman, J., and M. Huberty. 2014. Can Green Sustain Growth? Stanford, CA: Stanford Business Books. 